Vol. 4 No. 3 September 2017

\title{
KEWAJIBAN NOTARIS DALAM MENJALANKAN PRINSIP TATA KELOLA KANTOR NOTARIS YANG BAIK DAN PROFESIONAL(GOOD CORPORATE PUBLIC NOTARY) MENURUT UU NOMOR 30 TAHUN 2004 JUNCTO UU NOMOR 2 TAHUN 2014 TENTANG JABATAN NOTARIS
}

\author{
Adi Prasetiyo*, Gunarto** \\ * Mahasiswa Program Magister (S2) Kenotariatan Fakultas Hukum UNISSULA email: adiprasetiyo254@gmail.com \\ ** Dosen Fakultas Hukum UNISSULA
}

\begin{abstract}
Notary in performing his duties acting as public servant in the affairs of making the deed of agreement which is the will of the parties who want to make it. In order to improve notary services as much as possible one of them is with the notary's office itself. Notary obligation in implementing good corporate public notary principles must be consistent with Law Number 30 Year 2004 juncto Law Number 2 Year 2014 regarding Notary Position and referring to the Notary Code of Ethics, as well as from inventory office, employees, documentation and services to clients. The constraints often faced in carrying out the principles of office governance is arising from the notary itself and from employees, where the notary is involved in a criminal case that causes punishment and employees who act dishonestly in carrying out their work, thus causing harm to office management itself and become disorganized in its management.
\end{abstract}

Keywords: notary, office

\section{PENDAHULUAN}

Notaris adalah pejabat umum yang diangkat oleh pemerintah untuk membantu masyarakat dan pejabat umum yang berwenang membuat akta otentik sebagaimana yang telah diatur didalam Undang-Undang Nomor2 Tahun2 014 tentang Jabatan Notaris. Profesi notaris sendiri merupakan jabatan dan merupakan bagian dari eksekutif sehingga seorang yang secara akademik memiliki kapasitas untuk menjadi notaris namun tidak dilakukan pengangkatan oleh pemerintah maka seorang tersebu tidak dapat dikatakan menjadi seorang notaris. Dalam profesi jabatan notaris berlaku kaidah-kaidah etika yang berlaku yaitu profesi merupakan suatu pelayanan karena itu mereka harus bekerja tanpa pamrih, terutama bagi klien yang tidak mampu, pelayanan profesional dalam mendahulukan kepentingan klien yang tetap mengacu kepada kepentingan atau nilai-nilai luhur sebagai norma kritik yang memotivasi sikap dan tindakan, harus selalu berorientasi pada masyarakat secara menyeluruh dan agar persaingan dalam menjalankan pelayanan berlangsung secara sehat sehingga dapat menjamin mutu dan peningkatan mutu pengemban profesi maka harus mempunyai semangat solidaritas terhadap sesama rekan seprofesi.

Dalam meningkatkan pelayanan yang maksimal dari seorang notaris salah satunya adalah dari kantor notaris itu sendiri sebab dalam hal mengelola kantor yangbaik dapat menimbulkan kesan yang baik pula bagi notarisnya itu sendiri. Sebuah kantor yang semua bagiannya sesuai dengan kebutuhan dan fungsinya, ruangannya selalu tertata rapi dan bersih dapat memberikan kesan nyaman dan dapat dipercaya. Seperti yang telah kita ketahui bahwa kebutuhan lembaga notaris dalam praktek hukum sehari-har itidak bisa dilepaskan meningkatnya tingkat perekonomian dan kesadaran hukum masyarakat. Maka dari itu dalam menata perkantoran sangatlah penting bagi seorang notaris untuk meningkatkan pelayanannya sebab pelayanan dalam dunia kenotariatan harus 
tetap mengacu kepada UUJN dan Kode Etik Notaris.

\section{METODE PENELITIAN}

Metode penelitian yang digunakan dalam penulisan tesis ini adalah menggunakan metode penelitian yuridis normatif, artinya metode ini dilakukan dengan cara meneliti bahan pustaka atau data sekunder belaka. Pendekatan yuridis mengacu kepada hukum dan peraturan perundang-undangan yang berlaku, sedangkan pendekatan normatif dilakukan dengan cara meneliti bahan pustaka atau data sekunder terhadap asas-asas hukum serta studi kasus atau biasa disebut dengan penelitian hukum perpustakaan.

Spesifikasi penelitian dalam penulisan ini bersifat deskriptif analitis yang terbatas pada usaha mengungkapkan suatu masalah atau keadaan atau peristiwa sebagaimana adanya, sehingga bersifat sekedar mengungkapkan fakta. Penelitian terhadap teori dan praktek digunakan dengan tujuan untuk memperoleh gambaran tentang penerapan suatu teori didalam masyrakat dan untuk melukiskan kenyataan-kenyataan yang ada dan menggambarkan obyek yang menjadi pokok permasalahan. Dalam hal teknik pengumpulan data menggunakan studi dokumen dengan tujuan untuk memperoleh informasi dalam bentuk ketentuan formal dan naskah resmi yang ada dan wawancara dengan bertanya jawab secara langsung kepada pihak-pihak yang diwawancarai terutama kepada orang-orang yang berwenang, mengetahui dan terkait dengan peran kode etik notaris.

Metode analisis data yang digunakan sendiri adalah dengan analisis kualitatif yaitu data yang diperoleh melalui penelitian lapangan dan penelitian kepustakaan yang kemudian disusun secara sistematis dan selanjutnya dianalisa secara kualitatif untuk mencapai kejelasan masalah yang akan dibahas yang kemudian data tersebut akan dianalisa secara interpretatif menggunakan teori maupun hukum positif yang telah dituangkan kemudian secara deduktif ditarik kesimpulan untuk menjawab permasalahan yang ada.

\section{HASIL PENELITIAN DAN PEMBAHASAN}

Kewajiban notaris dalam menjalankan prinsip tata kelola kantor notaris yang baik dan profesional (good corporate public notary) tidaklah lepas dari kewenangan dan kewajiban notaris sebagai pejabat umum itu sendiri yang sesuai dengan Undang-Undang Jabatan Notaris dan Kode Etik Notaris, selain itu juga didukung dengan sistem administrasi, manajemen dan pelayanan yang baik kepada masyarakat atau klien. Berdasarkan pada Undang-Undang Nomor2 Tahun 2014 tentang Perubahan Atas Undang-Undang Nomor 30 Tahun 2004 tentang Jabatan Notaris dalam Pasal 15 menyataka ntentang kewenangan notaris yang salah satunya adalah notaris berwenang membuat Akta autentik mengenai semua perbuatan, perjanjian, dan penetapan yang diharuskan oleh peraturan perundang-undangan dan atau yang dikehendaki oleh yang berkepentingan untuk dinyatakan dalam akta autentik, menjamin kepastian tanggal pembuatan akta, menyimpan akta, memberikan grosse, salinan dan kutipan akta, semuanya itu sepanjang pembuatan akta itu tidak juga ditugaskan atau dikecualikan kepada pejabat lain atau orang lain yang ditetapkan oleh undang-undang. Selain kewenangan sebagaimana dimaksud pada ayat (1), notaris berwenang pula mengesahkan tanda tangan dan menetapkan kepastian tanggal surat dibawah tangan dengan mendaftar dalam buku khusus, membukukan surat di bawah tangan dengan mendaftar dalam buku khusus, membuat kopi dari asli surat dibawah tangan berupa salinan yang memuat uraian sebagaimana ditulis dan digambarkandalam suratyang bersangkutan, melakukanpengesahan kecocokanfotokopidengan surataslinya, memberikanp enyuluhan hukum sehubungan dengan pembuatan Akta, membuat Akta yang berkaitan dengan pertanahan, membuat Akta risalah lelang.

Berdasarkan Undang-Undang Nomor30 Tahun2004 jo. Undang-UndangNomor 2Tahun2 014 tentang Jabatan Notaris, kewenangan disini antara lain kewenangan mensertifikasikan transaksi yang dilakukan secara elektronik (cybernotary) termasuk ikrar wakaf dan hipotek pesawat terbang. Terhadap definisi yang diberikan 
oleh Pasal1 UUJN pada hakikatnya masih ditambahkan "yang dilengkapi dengan kekuasaan umum", oleh karena Grosse dari akta Notaris yang memuat kewajiban untuk melunasi suatu jumlah uang, yang pada bagian kepala akta memuat perkataan "Demi Keadilan Berdasarkan KetuhananYang Maha Esa", mempunyai kekuatan eksekutorial yang sama seperti yang diberikan kepadaputusan hakim.

Berdasarkan bunyi Pasal 15 ayat (1) UUJN tersebut, dapat dilihat bahwa disatu sisi wewenang notaris diberikan secar luas, namun disisi yang lain diberikan pembatasan terhadap wewenang tersebut. Pertama-tama dinyatakan bahwa notaris berwenang untuk membuat akta otentik, hanya apabila hal itu dikehendaki atau diminta oleh yangberkepentingan, sertatidak membuataktayang bukan menjadi tugas Notaris, ini berart ibahwa notaris tidak berwenang membua takta otentik diluar jabatan yang seharusnya wewenangnya terbatas pada pembuatan akta - akta dibidang hukum perdata. Perbuatan hukum yang tertuang dalama kta notaris bukanlah merupakan perbuatan hukum dari notaris sendiri, melainkan merupakan perbuatan hukum dari pihak - pihak yang minta atau menghendaki perbuatan hukum itu dituangkan dalam suatu akta notaris.

Sedangkan mengenai kewajiban notaris, disebutkan dalam Pasal 16 Undang-Undang Jabatan Notaris bahwa salah satunya dalam ayat (1) menyebutkan notaris dalam menjalankan jabatannya wajib :

1. Bertindak amanah, jujur, saksama, man diri, tidak berpihak, dan menjaga kepentingan pihak yang terkait dalam perbuatan hukum;

2. Membuat Akta dalam bentuk Minuta Akta dan menyimpannya sebagai bagian dari Protokol Notaris;

3. Melekatkan surat dan dokumen serta sidik jari penghadap pada Minuta Akta;

4. Mengeluarkan Grosse Akta, Salinan Akta, ata uKutipan Akta berdasarkan Minuta Akta;

5. Memberikan pelayanan sesuai dengan ketentuan dalam Undang-Undang ini, kecuali ada alasan untuk menolaknya;

6. Merahasiakan segala sesuatu mengenai Akta yang dibuatnya dan segala keterangan yang diperoleh guna pembuatan Akta sesuai dengan sumpah/ janji jabatan, kecuali undang-undang menentukan lain;

7. Menjilid Akta yang dibuatnya dalam 1 (satu) bulan menjadi buku yang memuat tidak lebih dari 50 (limapuluh) Akta, dan jika jumlah Akta tidak dapat dimuat dalam suatu buku, Akta tersebut dapat dijilid menjadi lebih dari satu buku, dan mencatat jumlah minuta Akta, bulan, dan tahun pembuatannya pada sampul setiap buku;

8. Membuat daftar dari Akta protes terhadap tidak dibayar atau tidak diterimanya surat berharga;

9. Membuat daftar Akta yang berkenaan dengan wasiat menurut urutan waktu pembuatan Akta setiap bulan;

10. Mengirimkan daftar Akta sebagaimana dimaksud dalam huruf i atau daftar nihil yang berkenaan dengan wasiat ke pusat daftar wasiat pada kementerian yang menyelenggarakan urusan pemerintahan dibidang hukum dalam waktu 5 (lima) hari pada minggu pertama setiap bulan berikutnya;

11. Mencatat dalam repertorium tanggal pengiriman daftar wasiat pada setiap akhir bulan;

12. Mempunyai cap atau stempel yang memuat lambang negara Republik Indonesia dan pada ruang yang melingkarinya dituliskan nama jabatan, dan tempat kedudukan yang bersangkutan;

13. Membacakan Akta dihadapan penghadap dengan dihadiri oleh paling sedikit 2 (dua) orang saksi, atau 4 (empat) orang saksi khusus untuk pembuatan Akta wasiat dibawah tangan, dan ditandatangani pada saat itu juga oleh penghadap, saksi dan Notaris;dan

14. Menerima magang calon Notaris.

Mengenai bentuk dan ukuran cap ataus tempel notaris sebagaimana dimaksud dalam Pasal 16 ayat (1) huruf I tentang Undang-Undang Jabatan Notaris, diatur lebih lanjut dalam Peraturan Menteri Hukum dan Hak Asasi Manusia Republik Indonesia Nomor M02.H T.0 3.10 Tahun 2007 tentang Bentuk dan Ukuran Cap/ Stempel Notaris di dalam Pasal 2 yang menyatakan bahwa : 
1. Cap/stempel Notaris berbentuk lingkaran dengan ukuran lingkaran luar berdiameter 3,5 (tiga koma lima) sentimeter dan lingkaran dalam 2,5 (dua koma lima) sentimeter.

2. Jarak antara lingkaran luar dan lingkaran dalam sebagaimana dimaksud pada ayat (1) 0,5 (nol koma lima) sentimeter.

3. Ruang pada lingkaran dalam memuat lambang Negara Republik Indonesia.

4. Ruang di antara lingkaran luar dan lingkaran dalam sebagaimana dimaksud pada ayat (2) dituliskan nama alamat lengkap atau nama lengkap dan gelar, jabatan dan tempat kedudukan Notaris yangb ersangkutan.

Selain hal tersebut, dalam Pasal 17 ayat (1) UU Nomor 30 Tahun 2004 juncto UU Nomor 2 Tahun 2014 tentang Jabatan Notaris, notaris dilarang menjalankan jabatan diluar wilayah jabatannya, meninggalkan wilayah jabatanny alebih dari 7 (tujuh) hari kerja berturut-turut tanpa alasan yang sah, merangkap sebagai pegawai negeri, merangkap jabatan sebagai pejabat negara, merangkap jabatan sebagai advokat, merangkap jabatan sebaga ipemimpin atau pegawai badan usaha milik negara, badan usaha milik daerah atau badan usaha swasta, merangkap jabatan sebagai Pejabat Pembuat Akta Tanah dan/ atau Pejabat Lelan Kelas II di luar tempat kedudukan Notaris, menjadi Notaris Pengganti dan Melakukan pekerjaan lain yang bertentangan dengan norma agama, kesusilaan, atau kepatutan yang dapat mempengaruhi kehormatan dan martabat jabatan notaris.

Berdasarkan Perubahan Kode Etik Notaris

Kongres Luar Biasa Ikatan Notaris Indonesia di Banten pada tanggal 29-30 Mei 2005, dalam BAB III Pasal 3, notaris maupun orang lain (selama yang bersangkutan menjalankan jabatan Notaris) wajib :

1. Memiliki moral, akhlak serta kepribadian yang baik;

2. Menghormati dan menjunjung tinggi harkat dan martabat Jabatan Notaris;

3. Menjaga dan membela kehormatan Perkumpulan;

4. Berperilaku jujur, mandiri, tidak berpihak, amanah, seksama, penuh rasa tanggung- jawab, berdasarkan peraturan perundangundangan dan isi sumpah jabatan Notaris;

5. Meningkatkan ilmu pengetahuan dan keahlian profesi yang telah dimiliki tidak terbatas pada ilmu pengetahuan hukum dan kenotariatan;

6. Mengutamakan pengabdian kepada kepentingan masyarakat dan Negara;

7. Memberikan jasa pembuatan akta dan kewenangan lainnya untuk masyarakat yang tidak mampu tanpa memungut honorarium;

8. Menetapkan satu kantor ditempat kedudukan dan kantor tersebut merupakan satu-satunya kantor bagi Notaris yang bersangkutan dalam melaksanakan tugas jabatan sehari-hari;

9. Memasang 1 (satu) papan nama didepan/ dilingkungan kantornya dengan pilihan ukuran yaitu $100 \mathrm{~cm} \times 40 \mathrm{~cm}, 150 \mathrm{~cm} \times 60 \mathrm{~cm}$ atau $200 \mathrm{~cm} \times 80 \mathrm{~cm}$, yang memuat :

a. Nama lengkap dan gelar yang sah;

b. Tanggal dan Nomor Surat Keputusan pengangkatan yang terakhir sebagai Notaris;

c. Tempat kedudukan;

d. Alamat kantor dan nomor telepon/fax.

Dasar papan nama berwarna putih dengan huruf berwarna hitam dan tulisan diatas papan nama harus jelas dan mudah dibaca. Kecuali dilingkungan kantor tersebu tidak dimungkinkan untuk pemasangan papan nama dimaksud.

10. Hadir, mengikuti dan berpartisipasi aktif dalam kegiatan yang diselenggarakan oleh Perkumpulan;

11. Menghormati, mematuhi, melaksanakan peraturan-peraturan dan keputusankeputusan Perkumpulan;

12. Membayar uang iuran Perkumpulan secara tertib;

13. Membayar uang duka untuk membantu ahli waris teman sejawat yang meninggal dunia;

14. Melaksanakan dan mematuhi semua ketentuan tentang honorarium yang ditetapkan Perkumpulan;

15. Menjalankan jabatan Notaris dikantornya, kecuali karena alasan-alasan tertentu;

16. Menciptakan suasana kekeluargaan dan kebersamaan dalam melaksanakan tugas jabatan dan kegiatan sehari-hari serta saling 
memperlakukan rekan sejawat secara baik, saling menghormati, saling menghargai, saling membantu serta selalu berusaha menjalin komunikasi dan tali silaturahmi;

17. Memperlakukan setiap klien yang datang dengan baik, tidak membedakan status ekonomi dan/ atau status sosialnya;

18. Membuat akta dalam jumlah batas kewajaran untuk menjalankan peraturan perundangundangan, khususnya Undang-Undang tentang Jabatan Notaris dan Kode Etik.

Selain itu berdasarkan dengan Pasal 4 Kode Etik Notaris, notaris maupun orang lain selama yang bersangkutan menjalankan jabatan Notaris) dilarang :

1. Mempunyai lebih dari 1 (satu) kantor, baik kantor cabang ataupun kantor perwakilan;

2. Memasang papan nama dan/ atau tulisan yang berbunyi "Notaris/KantorNotaris" di luar lingkungan kantor;

3. Melakukan publikasi atau promosi diri, baik sendiri maupun secara bersama-sama, dengan mencantumkan nama dan jabatannya, menggunakan sarana media cetak dan/ atau elektronik, dalam bentuk :
a. Iklan;
b. Ucapan selamat;
c. Ucapan belasungkawa;
d. Ucapan terimakasih;
e. Kegiatan pemasaran;
f. Kegiatan sponsor, baik dalam bidang sosial, keagamaan, maupun olah aga.

4. Bekerjasama dengan birojasa/ orang/ Badan Hukum yang pada hakekatnya bertindak sebagai perantara untuk mencari atau mendapatkan klien;

5. Menandatangani akta yang proses pembuatannya telah dipersiapkan oleh pihak lain;

6. Mengirimkan minuta kepada klien untuk ditandatangani;

7. Berusaha atau berupaya dengan jalan apapun, agar seseorang berpindah dari Notaris lain kepadanya ,baik upaya itu ditujukan langsung kepada klien yang bersangkutan maupun melalui perantaraan orang lain;
8. Melakukan pemaksaan kepada klien dengan cara menahan dokumen-dokumeny ang telah diserahkan dan/ atau melakukan tekanan psikologis dengan maksud agar klien tersebut tetap membuat akta padanya;

9. Melakukan usaha-usaha, baik langsung maupun tidak langsung yang menjurus kearah timbulnya persaingan yang tidak sehat dengan sesama rekan Notaris;

10. Menetapkan honorarium yang harus dibayar oleh klien dalam jumlah yang lebih rendah dari honorarium yang telah ditetapkan perkumpulan;

11. Mempekerjakan dengan sengaja orang yang masih berstatus keryawan kantor Notaris lain tanpa persetujuan terlebih dahulu dari Notaris yang bersangkutan, termasuk menerima pekerjaan dari karyawan kantor Notaris lain;

12. Menjelekkan dan /ata umempersalahkan rekan Notaris atau akta yang dibuat olehnya. Dalam hal seorang Notaris menghadapi dan/ata umenemukan suatu akta yang dibuat oleh rekan sejawat yang ternyata didalamnya terdapat kesalahan-kesalahan yang seriusd an/atau membahayakan klien, mak aNotaris tersebu twajib memberitahukan kepada rekan sejawat yang bersangkutan atas kesalahan yang dibuatnya dengan cara yang tidak bersifat menggurui, melainkan untuk mencegah timbulnya hal-hal yang tidakd diinginkan terhadap klien yang bersangkutan ataupun reka nsejawat tersebut;

13. Tidak melakukan kewajiban dan melakukan pelanggaran terhadap larangan sebagaimana dimaksud dalam Kode Etik dengan menggunakan media elektronik, termasuk namun tidak terbatas dengan menggunakan internet dan media sosial;

14. Membentuk kelompok sesama rekan sejawat yang bersifat eksklusif dengan tujuan untuk melayani kepentingan suatu instansi atau lembaga, apalagi menutup kemungkinan bagi Notaris lain untuk berpartisipasi;

15. Menggunakan dan mencanumkan gelar yang tidak sesuai dengan peraturan perundangundangan yang berlaku; 
16. Membua takta melebihi batas kewajaran yang batas jumlahnya ditentukan oleh Dewan Kehormatan;

17. Mengikuti pelelangan untuk mendapatkan pekerjaan/pembuatan akta.

Sehingga dengan mentaati peraturan tentang kewenangan, kewajiban danlarangan bagi notaris yang tertuang dalam Undang-Undang Nomor 2 Tahun 2014 tentang Perubahan Atas Undang-Undang Nomor 30 Tahun 2004 tentang Jabatan Notaris serta peraturan menteri lainnya yang mengikat, maka notaris dapat menjalankan tugas jabatannya dengan baik. Seorang notaris selain harus mentaati Undang-Undang Jabatan Notaris juga harus tunduk dan patuh terhadap Kode Etik Notaris yang dibentuk oleh Ikatan Notaris Indonesia disingkat INI yang merupakan perkumpulan atau organisasi bagi para notaris, serta berdiri semenjak tanggal 1 Juli 1907, diakui sebagai Badan Hukum (rechtspersoon) berdasarkanGouvernementsBes/uit (Penetapan Pemerintah) tanggal 5 September 1908 Nomor9, merupakan satu-satunya wadah pemersatu bagi semua dan setiap orang yang memangku dan menjalankan tugas jabatan sebagai pejabat umum di Indonesia.

Sebagaimana yang telah diamanatkan pula dalam undang-undang dan kode etik notaris bahwa dalam menjalankan jabatannya notaris harus pula mempunyai satu kantor yang berada di dalam satu wilayah kabupaten atau kota dengan berlandaskan Undang-Undang Jabatan Notaris, kode etik notaris, peraturan menteri dan peraturan lainnya. Dimana dalam menjalankan suatu kantor yang baik selain harus memperhatikan peraturan perundang-undangan juga harus memiliki prinsip tata kelola kantor notaris yang baik (good corporate public notary). Administrasi dan manajemen yang lebih baik bagi kantor notaris bertujuan untuk tugas yang profesional sehingga pelayanan terhadap klien dapat diselesaikan dengan cepat dan tepat. Kemudian laporan atas tugas dan tanggungjawab kepada Majelis Pengawas Daerah dan institusi terkait juga cepat, tepat dan tertib. Pentingnya legal asisten bagi notaris yang merupakan jasa-jasa notaris dalam ranah ekonomi, memberikan nilai ekonomis bagi klien, bagi pemerintah, stakeholder dan tentunya bagi notaris yang bersangkutan. Notaris tidak dapat bekerja sendiri melainkan membutuhkan asisten dan sumber daya manusia yang sesuai kompetensinya, untuk itu harus mengikuti pendidikan keahlian secara khusus dan tepat dapat dimanfaatkan.

Antara legal asisten dan staf, masing-masing mempunyai kesempatan untuk memenuhi tugas profesional. Dibutuh latihan dengan cara terencana dan terkoordinasi, dididik dan diintegrasikan dalam organisasi. Perencanaan organisasi harus seirama dengan perencanaan administrasi dan manajemen yang efektif dan efisien. Administrasi dan manajemen kantor, merupakan proses perencanaan, pengorganisasian dan pengkoordinasian manusia, bahan-bahan, mesinmesin, metoda, perlengkapan, peralatan dan uang, serta pengarahan dan pengawasan atas pelaksanaan pekerjaan dalam rangka mencapai tujuan organisasi. Keberhasilan seorang notaris tidak hanya bisa diukur dari banyaknya akta yang ia buat, melainkan juga dari kepiawaiannya mengatur administrasi dikantornya. Akta yang banyak, tanpa disertai administrasi yang rapi dan teratur akan mengakibatkan masalah dan kesulitan dikemudian hari. Oleh karena itu perlu bagi seorang calon Notaris untuk mengetahui, mempelajari serta memperhatikan administrasi kantor, sebelum ia melaksanakan jabatannya sebagai seorang Notaris agar terwujudnya good corporate public notary. Oleh karena itu, kewajiban notaris dalam menjalankan prinsip tata kelola kantor notaris yang baik dan profesional (good corporate public notary) tidak hanya terbatas pada berapa banyak jumlah akta yang dibuat setiap bulannya, melainkan terlihat dari bagaimana cara ia mengelola administrasi kantornya itu dan pelayanan dalam dunia kenotariatan harus tetap mengacu dan patuh pada UU Nomor 30 Tahun 2004j uncto UU Nomor 2 Tahun 2014 tentang Jabatan Notaris dan kode etik notaris yang telah disahkan, sehinggas eorang notaris yang memberikan pelayanan kepada kliennya tidak boleh mengorbankan keluhuran dan martabat notariss ebagai pejabat umum.

Berkaitan dengan melaksanakan tugas administrasi kantornya pasti ditemukan beberapa 
kendala-kendala yang dihadapi oleh seorang notaris itu sendiri. Berkenaan dengan hal tersebut seorang notaris yang profesional dari segi ilmu yaitu dituntut untuk mendalami ilmu pengetahuan khususnya dalam bidang hukum keperdataan, tidak hanya hukum keperdataan saja tetapi ilmu pengetahuan lainnya. Selain itu juga harus lebih berpengalaman di dalam dunia prakteknya dengan menjalani magang atau bekerja sebagai karyawan notaris, agar terciptanya das sein dan das sollen yang baik. Sehingga dapat menjadi Notaris yang profesional dalam menjalani tugas jabatannya. Oleh karena itu, pada kenyataannya kendala tersebut dapat muncul dari notaris itu sendiri atau timbul dari karyawan yang bekerja pada kantor notaris tersebut. Kendala yang muncul dalam notaris itu sendiri yaitu notaris yang terseret pada perkara pidana yang menyangkut harkat dan martabatnya. Selain dari pihak notaris, terdapat juga masalah yang ditimbulkan dari pihak karyawan yaitu dengan adanya karyawan yang tidak jujur seperti menggunakan uang pajak yang seharusnya digunakan sebagaimana mestinya, memalsukan tandatangan notaris itu sendiri, terdapat suatu pekerjaan yang masuk tetapi ditangani sendiri dan tidak diberitahukan kepada notaris yang bersangkutan, serta kelalaian karyawan yang tidak segera mencatat dokumen yang masuk dan keluar pada saat itu juga, sehingga menimbulkan nomor atau tanggal yang ganda. Hal tersebut berpengaruh kepada tata kelola kantor notaris itu sendiri, dengan adanya suatu manajemen yang tidak tertib dan teratur, serta kelalaian baik dari notaris itu sendiri maupun dari karyawan. Oleh karena itu, sebagai notaris harus menjalankan amanat sesuai dengan Undang-Undang Jabatan Notaris dan Kode Etik Notaris, serta dalam memilih karyawan ada baiknya harus disiplin dan memilih karyawan yang jujur, amanah dan bertanggung jawab agar dapt dipercaya.

\section{KESIMPULAN}

Kewajibannotarisdalam menjalankanprinsip tatakelola kantornotarisyangbaik dan profesional (goodcorporatepublicnotary) harus tetap mengacu kepada Undang-Undang Nomor30 Tahun 2004 juncto Undang-Undang Nomor2 Tahun 2014 tentang Jabatan Notaris dan Kode Etik Notaris. Serta pengelolaannya terhadap administrasi dan manajemen kantor yang baik mulai dari inventaris kantor, karyawan, pendokumentasian atau tata kearsipan dan pelayanan terhadap klien. Sehingga notarisyang memberikan pelayanan kepada kliennya tidak boleh mengorbankan keluhuran dan martabat notaris sebagai pejabat umum.

Selain itu, kendala yang dihadapi oleh seorang notaris dalam menjalankan prinsip tata kelola kantor notaris adalah timbul dari notaris itu sendiri dan karyawan notaris yang bekerja pada kantor notaris yang bersangkutan. Notaris yang tersangkut kasus pidana dan menerima hukuman pidana serta adanya karyawan notaris yang berkerja tidak jujur, amanah dan bertanggung jawab dapat mengganggu tata kelola kantor notaris itu sendiri, yang menyebabkan manajemen kantor notaris menjadi tidak baik serta menjadi berantakan.

\section{SARAN}

Kewajiban notaris dalam menjalankan prinsip tata kelola kantor untuk tugas jabatannya sudah sesuai dengan peraturan perundang-undangan, kode etik notaris, peraturan menteri dan peraturan perundang-undangan lainnya. Namun dalam hal tata kelola kantor notaris sebaiknya dibentuk lagi secara tegas dalam suatu peraturan yang dibentuk melalui organisasi baik untuk visi, misi dan tujuan, walaupun notaris adalah seorang pribadi tetapi dalam menjalankan sebuah kantor sama halnya seperti dengan perusahaan yang menganut pada Good Corporate Governence (GCG), agar lebih terciptanya kantor yang terorganisir.

Untuk menjadi notaris yang profesional dan handal dari segi ilmu dan moral sudah sesuai dengan kaidah moral yangterdapatdalamundangundangdankodeetik, tetapi sebaiknya untuk lebih memperdalam ilmu pengetahuan dan moral itu sendiri untuk menjadi seorang notaris harusnya dibentuk sebuah pelatihan khusus notaris setelah lulus dari jenjang strata dua kenotariatan. Pelatihan tersebut dapat dibentuk melalui organisasi yang disetujui oleh keputusan menteri yang bersangkutan, sehingga dalam melaksanakan 
tugas jabatannya benar-benar dibekali ilmu pengetahuan dan moral yang mendalam.

\section{DAFTAR PUSTAKA}

Undang-Undang Nomor 2 Tahun 2014 tentang Perubahan Atas Undang-Undang Nomor 30 Tahun 2004 tentang Jabatan Notaris.
Undang-Undang Nomor 30 Tahun 2004 tentang Jabatan Notaris.

Peraturan Menteri Hukum dan Hak Asasi Manusia Republik Indonesia Nomor M.02.HT.03.10 Tahun 2007 tentang Bentuk dan Ukuran Cap/Stempel Notaris.

Kode Etik Notaris. 